Uluslararası Yönetim Íktisat ve İsletme Dergisi, ICAFR 16 Özel Sayısı

Int. Journal of Management Economics and Business, ICAFR 16 Special Issue

\title{
SIVIIL TOPLUM KURULUŞLARINDAN (STK) VAKIFLARDA MUHASEBE VE VERGİ UYGULAMALARI
}

\author{
Öğr. Gör. Dr. Nisa Kıymet ŞAHİN \\ Balıkesir Üniversitesi, Bigadiç MYO \\ nisasahin@balikesir.edu.tr
}

\section{ÖZET}

Günümüzde Sivil Toplum Kuruluşları (STK), toplumsal ve siyasal yaşamda önemli bir rol oynamakta ve demokratik bir sistem için vazgeçilmez bir konumda bulunmaktadırlar. Sivil Toplum Kuruluşlarındaki gelişmeleri izlemek ve yönlendirmek ancak sağlıkl mali bilgiler elde etmekle mümkündür. Kâr amacl gütmeyen bu kuruluşların, kamusal nitelikli hizmetleri dolayısıla yaptıkları ekonomik faaliyetler, tüm ülkelerde mali açıdan farklı işlemlere tabi tutulmaktadır.

Bu çalışmada, temelde gönüllülük esasına dayalı ve kar amacı gütmeyen vakıfların; kendilerine mahsus bazı özellikleri dolayısıyla, kar amaçlı ticari işletmelerden muhasebe işlemleri yönünden ortaya çıkan farklılıkları açıklanmaya çalışılacaktır. Ayrıca vakıfların vergi kanunları karşlsındaki genel durumları, istisna ve muafiyetleri üzerinde durulacaktır.

\section{Anahtar sözcükler: STK, Vakif Muhasebesi, Vakuflarda Vergi Uygulamaları. \\ ACCOUNTING AND TAX IMPLEMENTATIONS IN FOUNDATIONS WHICH ARE ONE OF THE NGOS}

\section{ABSTRACT}

Today, Non-Governmental Organizations (NGO) play an important role both in social and political life and they stand in an indispensable position in a democratic system. Monitoring and directing the developments in Non-Governmental Organizations can only be possible by obtaining reliable financial information. Economic activities and public services of these non-profit organizations are subjected to differences in financial terms in all countries.

In this study, the differences between the accounting procedures of the foundations which are non-profit institutions basically based on volunteering and the for-profit enterprises have been explained. Furthermore, general positions of the foundations before the tax laws, exceptions and exemptions have been discussed.

Key words: NGO, Foundation Accounting, Tax Implementations In Foundations.

\section{Giriş}

Tüm dünyada kamu ve özel sektörün ardından ekonomiye katkı sağlayan Üçüncü Sektör olarak nitelendirilen (Özdemir vd., 2009:228) sivil toplum kuruluşları, kâr amac1 gütmeyen, bütün üyelerinin gönüllü çalıştığı ve gelişmiş ülkelerde topluma hizmet 


\section{Uluslararası Yönetim İktisat ve İsletme Dergisi, ICAFR 16 Özel Sayısı Int. Journal of Management Economics and Business, ICAFR 16 Special Issue}

götüren en önemli sosyal organizasyonlardır. Son yıllarda nicelik ve niteliklerinde hızlı bir artış gözlenen STK'lar içerisine; odalar, sendikalar, kooperatifler, özel sektör girişimleri, siyasi grup ve partiler, dernekler, vakıflar vb. tüm örgütleri koymak mümkündür.

Türkiye'de sivil toplum ve STK kavramı aslında 1980'ler ve sonrasının söylemidir. İcraatı ise, Selçuklular ve Osmanlılar döneminde kurulmuş ve devlete ait sosyal hizmetlerin bir kısmını yüklenen Vakıf müessesesine kadar uzanır. (Erşahin, 2003:27-28). Özellikle de 1967 yılında Bakanlar Kurulunca çıkarılan bir kararname ile vakıflara vergi muafiyetlerinin sağlanması ve vakıflara yapılan bağışlara getirilen çeşitli vergi indirimleri üzerine, Türkiye'de sayılarında önemli bir artış olan vakıflar ve onlara bağlı iktisadi işletmeler ülke ekonomisinde önemli bir yer tutmaktadır. Vakıfların, kar amacı gütmeyen kuruluşlardan olması bunlarda uygulanan muhasebe sisteminin diğer işletmelerden farklı olması sonucunu doğurmuştur. Çalışmada, bu temelden hareketle, vakıfların muhasebe uygulamaları ve vergi mevzuatı açısından durumları incelenmeye çalışılacaktır.

\section{Vakıflara İlişkin Genel Bilgiler}

1.1.2002 tarihinde yürürlüğe giren 4721 sayılı Türk Medeni Kanunu'nun 101'inci maddesinde; vakıflar, gerçek veya tüzel kişilerin yeterli mal ve hakları belirli ve sürekli bir amaca özgülemeleriyle oluşan tüzel kişiliğe sahip mal toplulukları olarak tanımlanmıștır ${ }^{2}$. Vakıfların özellikleri; kar amacı olmaması, kurucularına çıkar sağlamaması ve toplum refahına hizmet etmesi olarak üç temel grupta toplanabilir (Bourgeois, 2003'den aktaran Durmuş, 2012:471).

Vakıfları, 1926 tarihinde kabul edilen Türk Medeni Kanunu'ndan önce ve sonra kurulmuş vakıflar olmak üzere sınıflandırmak mümkündür ${ }^{3}$. Medeni Kanunun kabulünden önce kurulan vakıflar Osmanlı İmparatorluğu döneminde kurulmuş olan ve günümüze kadar devam eden vakıflardır. Bu vakıflar 13.06.1935 tarihinde yürürlüğe giren 2762 sayılı Vakıflar Kanunu'na tabi olarak faaliyetlerini sürdürmektedirler. Bu kanun ile vakıflar; Mazbut Vakıflar, Mülhak Vakıflar, Cemaat ve Esnafa Mahsus Vakıflar olarak üç grupta toplanmıştır (Saydam \& Ekici, 1998:4). Cumhuriyet döneminden itibaren kurulmuş olan vakıflar, 1967 yılında Medenî Kanunda yapılan değişiklikle 903 sayılı Kanuna göre "Yeni Vakıflar" olarak adlandırılmaktadır.

Tablo 1. Vakıfların Türlerine Göre Dağılımı

\begin{tabular}{|l|r|}
\hline Mülhak Vakıf Sayısı & 274 Adet \\
\hline Cemaat Vakıf Sayısı & 167 Adet \\
\hline Esnaf Vakfı & 1 Adet \\
\hline Yeni Vakıf Sayısı & 5.012 Adet \\
\hline Yurtdışında Kurulan Vakıfların (Yabancı & 21 Adet \\
Vakıflar)Türkiye'deki Şube/Temsilcilik Sayısı & \\
\hline
\end{tabular}

Kaynak: http://www.vgm.gov.tr/db/dosyalar/webicerik195.pdf 31.12.2015

\subsection{Vakıf Muhasebesi Hakkında Genel Bilgiler}

${ }^{2}$ 08.12.2001 tarihli ve 24607 sayılı Resmi Gazete" de yayımlanmıştır.

${ }^{3}$ Vakıflarımız, (t.y.) http://www.vgm.gov.tr/sayfa.aspx?ld=35(10 Aralık 2010) 
Uluslararası Yönetim İktisat ve İşletme Dergisi, ICAFR 16 Özel Sayısı Int. Journal of Management Economics and Business, ICAFR 16 Special Issue

İktisadi faaliyette bulunan işletmeler amaçlarına göre kâr amacı güden ve kâr amacı gütmeyen işletmeler olarak ikiye ayrılmaktadır. Kâr amacı güden ve gütmeyen işletmeler arasındaki gaye farklılığı muhasebe uygulamalarına da yansımaktadır. Kar amacı gütmeyen sivil toplum kuruluşların muhasebe sistemi yönünden diğer işletmelerden farkı gelirlerin tahsili (şartlı-şartsız bağış) ve dönem sonundaki gelirlerin dağıtımıdır (Şanlı, 1980:29).

Toplumsal sorumluluk bilinciyle çalışan ve toplumun düşünsel refahına katkıda bulunmayı amaçlayan vakıfların, iyi yönetilip yönlendirilebilmesi, büyük ölçüde sağlıklı mali veriler elde edilmesine ve bunların doğru okunup iyi kullanılmasına bağlıdır. Sağlıklı ve güvenilir mali veriler ise iyi bir muhasebe sistemine dayanan kayıtlardan elde edilebilir (Konca, 2006:10). Vakıflarda hesap işleri, belgeleme, defter tutma, sonuç çıkarma ve raporlama, finansal analizler açısından önemli olduğu kadar, hesap verilebilirliğin sağlanabilmesi açısından da oldukça önemlidir (Durmuş, 2011:94).

\subsubsection{Vakıflarda Muhasebe Hesap Planı}

Vakıflar Genel Müdürlüğü, Vakıflar Yönetmeliği’nin 50. maddesinin 1. fikrasında, bilanço esasına göre defter tutmak zorunda olan yeni vakıflar (Türk Medeni Kanunu'na Göre Kurulmuş Vakıflar) ile mülhak, cemaat ve esnaf vakıflarının, muhasebe kayıtlarını Genel Müdürlüğün resmi internet sitesinde yayımlanan Vakıflar Tek Düzen Hesap Planına uygun olarak tutmaları, bilanço ve gelir tablolarını da bu plan ekindeki örnek tablolara göre düzenlemeleri gerektiği belirtilmiştir ${ }^{4}$.

$\mathrm{Bu}$ hesap planı, vakfa bağlı iktisadi işletmeler tarafindan kullanılmayacak olup, bağlı iktisadi işletmeler, 26.12.1992 tarih ve 21447 mükerrer sayılı Resmi Gazete'de yayımlanan 1 sıra numaralı MSUGT ekindeki hesap planını uygulayacaklardır (Öğredik, 2005:22). Vakıflar Tekdüzen Hesap Planı uygulanmasında, muhasebe sistemi uygulama genel tebliğine göre diğer işletmelerden farklı olarak bazı hesapların işleyişinde özellik arz eden durumlar söz konusudur.

Tablo 2. Tek Düzen Hesap Planında Bilanço Hesaplarında Vakıflar Açısından Farklılık Arz Eden Durumlar

\begin{tabular}{|l|l|}
\hline MUH.SíS.UYG.GEN.TEBL.T.D.H.P & VAKIFLAR T.D.H.P. \\
\hline 13- Diğer Alacaklar & 13-Diğer Alacaklar \\
131- Ortaklardan Alacaklar & 131-Ortaklardan (Kuruculardan) Alacaklar \\
133- Bağlı Ortaklıklardan Alacaklar & 133-Bağlı Ortaklıklardan Alacaklar (İktisadi \\
& İşletmelerden Alacaklar) \\
134 ---- & 134-Üyelerden Alacaklar \\
\hline 23- Diğgr Alacaklar & 23- Diğer Alacaklar \\
230- Ortaklardan Alacaklar & 231-Ortaklardan (Kuruculardan) Alacaklar \\
232- Bağlı Ortaklıklardan Alacaklar & 233-Bağlı Ortaklıklardan (İktisadi İşletmelerden) \\
& Alacaklar \\
234---- & 234-Üyelerden Alacaklar \\
\hline 24- Mali Duran Varlıklar & 24- Mali Duran Varlıklar \\
245- Bağlı Ortaklıklar & 245-Bağlı Ortaklıklar (İktisadi İşletmeler) \\
246- Bağlı Ortaklıklar Sermaye Taahhüdü (-) & 246-Bağlı Ortaklıklara (İktisadi İşletmelere) \\
& Sermaye Taahhütleri (-) \\
247- Bağlı Ortaklıklar Sermaye Payları Değer & 247-Bağlı Ortaklıklar (İktisadi İşletmelere) \\
Düşüklüğü Karşılığı (-) & Sermaye Payları Değer Düşüklüğü Karşıllı̆ı (-) \\
\hline
\end{tabular}

4 http://www.vgm.gov.tr/belgeler/Hesapplani.pdf 
Uluslararası Yönetim Íktisat ve İsletme Dergisi, ICAFR 16 Özel Sayısı Int. Journal of Management Economics and Business, ICAFR 16 Special Issue

\begin{tabular}{|c|c|}
\hline $\begin{array}{l}\text { 30-Mali Borçlar } \\
\text { 304-Tahvil Anapara Borç, Taksit Ve Faizleri } \\
\text { 305-Çıkarılmış Bonolar Ve Senetler } \\
\text { 306-Çıkarılmış Diğer Menkul Kıymetler } \\
\text { 308-Menkul Kıymetler İhraç Farkı (-) }\end{array}$ & $\begin{array}{l}\text { 30-Mali Borçlar } \\
\text { 304-(Kullanılmaz) } \\
\text { 305-(Kullanılmaz) } \\
\text { 306-(Kullanılmaz) } \\
\text { 308-(Kullanılmaz) }\end{array}$ \\
\hline 33-Diğer Borçlar & 33- Diğer Borçlar \\
\hline 331-Ortaklara Borçlar & 331-Ortaklara (Kuruculara) Borçlar \\
\hline 332-İştiraklere Borçlar & 332-İştiraklere Borçlar \\
\hline 333-Bağlı Ortaklıklara Borçlar & 333-Bağlı Ortaklıklara (İktisadi İşletmelere) \\
\hline 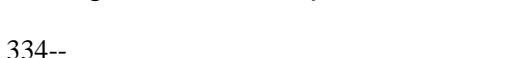 & $\begin{array}{l}\text { Borçlar } \\
\text { 334-Ï̈velere Borclar }\end{array}$ \\
\hline 40-Mali Borçlar & 40-Mali Borçlar \\
\hline 405-Çıkarılmıș Tahviller & 405-(Kullanılmaz) \\
\hline 407-Çıkarılmıș Diğer Menkul Kıymetler & 407-(Kullanilmaz) \\
\hline 408-Menkul Kıymetler İhraç Farkı (-) & 408-(Kullanılmaz) \\
\hline 43-Diğer Borçlar & 43- Diğer Borçlar \\
\hline 431-Ortaklara Borçlar & 431-Ortaklara (Kuruculara) Borçlar \\
\hline 432-İştiraklere Borçlar & 432-İstiraklere Borçlar \\
\hline 433-Bağlı Ortaklıklara Borçlar & 433-Bağlı Ortaklıkl. (İktisadi İşletmelere) Borçlar \\
\hline$\frac{\text { 434--- }}{50-\text { Ödenmis Sermave }}$ & 434-Üyelere Borçlar \\
\hline $\begin{array}{l}\text { 50-Udenmiş Sermaye } \\
\text { 500-Sermaye }\end{array}$ & $\begin{array}{l}\text { 50-Udenmış Sermaye } \\
\text { 500-Sermaye (Mal Varlığı) }\end{array}$ \\
\hline 501-Ödenmiş Sermaye (-) & 501-Ödenmiş Sermaye (-) \\
\hline 52-Sermaye Yedekleri & 52-Sermaye Yedekleri \\
\hline 520-Hisse Senetleri İhraç Primleri & 520-Kullanilmaz \\
\hline 521-Hisse Senedi İptal Kârları & 521-Kullanilmaz \\
\hline 54-Kâr Yedekleri & 54-Kâr Yedekleri \\
\hline 543------- & 543-Matematik Karşılıklar \\
\hline 544------- & 544-Ödenmemiş Prim Karşılı̆̆ \\
\hline 57-Geçmiş Yıllar Karları & 57-Geçmiș Yıllar Karları (Gelir Fazlaları) \\
\hline 570-Geçmiș Yıllar Karları & 570-Geçmiș Yıllar Karları (Gelir Fazlaları) \\
\hline 58-Geçmiş Y1llar Zararları & 58-Geçmiș Yıllar Zararları (-)(Gider Fazlaları) \\
\hline 580-Geçmiş Y1llar Zararları & 580-Geçmiş Yıllar Zararları (-)(Gider Fazlaları) \\
\hline 59-Dönem Net Karı & 59-Dönem Net Karı (Dönem Net Gelir Fazlası) \\
\hline 590-Dönem Net Karı & 590-Dönem Net Karı (Dönem Net Gelir Fazlası) \\
\hline 591-Dönem Net Zararı (-) & 591-Dön. Net Zararı (-) (Dön. Net Gider Fazlası) \\
\hline
\end{tabular}

Tablo 3. Tek Düzen Hesap Planında Gelir Tablosu Hesaplarında Vakıflar Açısından Farklılık Arz Eden Durumlar

\begin{tabular}{|l|l|}
\hline MUH.SIS.UYG.GEN.TEBL.T.D.H.P & VAKIFLAR T.D.H.P. \\
\hline 60- Brüt Satışlar & 60- Brüt Satışlar \\
603---- & 603- Bağış ve Yardımlar \\
604- --- & 604- Prim ve Aidatlar \\
\hline 63- Faaliyet Giderleri & 63- Faaliyet Giderleri \\
633--- & 633- Amacına Yönelik Giderler \\
\hline 64- Diğer Faaliyetlerden Olağan Gelir ve Karlar & 64- Diğer Faaliyetlerden Olağan Gelir ve \\
& Karlar \\
641 Bağlı Ortaklıklardan Temettü Gelirleri & 641-Bağlı Ortaklıklardan (İktisadi \\
& İşletmeler) Temettü Gelirleri \\
648---- & 648- İktisadi İşletme Gelirleri \\
\hline 69-Dönem Net Kârı (Zararı) & 69-Dönem Net Kârı (Zararı) \\
690-Dönem Kârı Veya Zararı & 691- Dönem Karı veya Zararı (Gelir veya \\
691-Dönem Kârı Vergi Ve Diğer Yasal Yükümlülük & Gider Fazlası) \\
Karşılıkları (-) & 692- Dönem Net Karı veya Zararı (Dönem \\
692-Dönem Net Kârı Veya Zararı & Net Gelir veya Gider Fazlası) \\
\hline
\end{tabular}


Uluslararası Yönetim İktisat ve İşletme Dergisi, ICAFR 16 Özel Sayısı Int. Journal of Management Economics and Business, ICAFR 16 Special Issue

Vakıfların muhasebe sistemindeki farklılıkları genel olarak şöyle sıralayabiliriz (Arslan, 1996; Kayıhan, 2012; Konca, 2006; Kurt, 2013; Öğredik, 2005; Saydam ve Ekici, 1998; SYD Vakfı Kayıt Nizamı, 2010; Şahin, 2013; VGM5):

- Vakıfların muhasebe kayıtlarını Genel Müdürlüğün resmi internet sitesinde yayımlanan Vakıflar Tekdüzen Hesap Planına uygun olarak tutmaları gerekir.

- Maliyet hesabı kullanma zorunluluğu olan vakıfların 7/B seçeneğine göre kayıt yapmaları öngörülmüştür.

- Vergi muafiyeti tanınan vakıflar ile yıllık brüt geliri her yıl Maliye Bakanlığınca belirlenen tutarının (1.1.2012'den itibaren 77.000 TL) üzerinde bulunan vakıflar mutlak surette bilanço esasına göre defter tutarlar. Bilanço esasına göre defter tutmak zorunda olmayan vakıfların işletme esasına göre defter tutabilirler. Yeni kurulan vakıflar, tescili izleyen en geç bir yıl içinde, Vakıflar Genel Müdürlüğünce yapılacak teftişe kadar işletme hesabı esasına göre defter tutabilirler.

- Vakıflar Yönetmeliğii'nin 51'inci maddesine göre de, Vakıflar;

a) İşletme hesabı esasında; karar defteri, işletme hesabı defteri ile bağış makbuzu kayıt defterini,

b) Bilanço esasında ise; karar defteri, yevmiye defteri, büyük defter, envanter defteri ile bağış makbuzu kayıt defterini, tutmak zorundadırlar.

- Vakıflar, defter onayı, kayıt düzeni, belge düzenleme ve temini hususlarında diğer işletmelerde olduğu gibi VUK ve TTK hükümlerine tabidir.

- Belirli bir amaç için kurulan vakıflar gayelerinin dışında faaliyet gösteremezler. Vakfedilen malların aslı satılamaz, hibe edilemez, miras bırakılamaz.

- Vakıf tüzüğünde yer almayan hiç bir faaliyet için gider yapılamaz, yapılırsa kuruculardan tahsil edilir. Vakıfların elektrik, su, telefon gibi ödemelerin geç yapılmasından doğan farklar ve cezalar kurucular tarafından ödenir.

- Vakıflar, varlıklarını, ekonomik kural ve riskleri gözetmek suretiyle değerlendirirler, Türkiye'de bütün vakıflar kasalarında ihtiyaç kadar para tutabilir (16 yaşından büyükler için belirlenen asgari brüt ücretin iki katından fazla nakit bulundurulmayacaktır); ihtiyaç fazlasını ise bankalara yatırmak zorundadır.

- Ticari işletmelerde kullanılan $150,151,152,153$ nolu stok hesaplarının vakıflar için kullanımı uygun olamadığından vakıflar stoklarını 157 Diğer Stoklar hesabında takip etmektedir.

- 3065 sayılı Katma Değer Vergisi Kanununda, Bakanlar Kurulunca vergi muafiyeti tanınan vakıflar, çeşitli teslim ve hizmetleri dolayısıyla katma değer vergisinden istisna edildiğinden KDV vakfın ilgili hesaplarına KDV dahil tutarlar olarak kaydedilir.

\footnotetext{
${ }^{5}$ http://www.vgm.gov.tr/sayfa.aspx?ld=45
} 
Uluslararası Yönetim İktisat ve İsletme Dergisi, ICAFR 16 Özel Sayısı Int. Journal of Management Economics and Business, ICAFR 16 Special Issue

- Vakıflar, kurumlar vergisine tabi olmadığından dolayı amortismana tabi iktisadi kıymetleri için aşınma payı ayırmalarına gerek bulunmamaktadır.

- 5735 sayılı Vakıflar Kanunu'nun 26’nc1 maddesinde:“Vakıflar; amacını gerçekleştirmeye yardımcı olmak ve vakfa gelir temin etmek amacıyla, Genel Müdürlüğe bilgi vermek şartıyla iktisadî işletme kurabilir, kurulmuş işletmelere ortak olabilirler. İktisadî işletmelerden elde edilen gelirler vakfın amacından başka bir amaca tahsis edilemez" hükmüne yer verilmiştir.

- Yeni vakıflar; merkez ve şubelerinin mali tablolarını ayrı ayrı tanzim ederek, yıl sonunda şubenin mali tabloları ile vakıf merkezinin mali tablolarının konsolide edilmesini sağlarlar.

- Bağış ödemelerinde, VUK'nun uygulamaya ilişkin tebliğine göre, şirketlerin veya şahısların 8.000 (Sekiz bin) TL'nin altındaki ödemeleri nakit olarak yapılabilir. Nakit bağışlar karşılığında bağış makbuzu düzenlenir. Banka havalesi ile yapılan bağışlarda, banka dekontu ödemeyi kanıtladığı için istenirse ayrıca makbuz düzenlenmesine gerek yoktur. Ancak vergi muafiyeti/ kamu yararı statüsüne sahip kuruluşların makbuz kesmesi zorunludur.

- Vakıflar kâr amaçlı olmadığından faaliyet dönemi sonunda ortaya çıkan fazlalık, gelir-gider farkı olarak adlandırılır. Bu fazlalığın dağıtımı söz konusu değildir.

- Vakıfların amaca ve yasalara uygunluk denetimi ile iktisadî işletmelerinin faaliyet ve mevzuata uygunluk denetimi Genel Müdürlükçe yapılır.

- Bütün vakıflar yılsonlarında bilanço, gelir-gider, varsa borç ve alacaklarını envanter defterine işlemek zorundadır.

- Vakıf yöneticileri, Vakıflar Yönetmeliği Ek-2'deki beyannameyi eksiksiz doldurup her takvim yılının ilk altı ayı içerisinde bölge müdürlüğüne vermek ve elektronik ortamda göndermek zorundadırlar.

- Vakıflarda ortaklık olmayacağından ve ticari işletmelerde ortaklara isabet eden kişiliğin kurucular olması nedeniyle Ortaklardan Alacaklar Hesabı Kuruculardan Alacaklar şeklinde değiştirilmiştir.

- Vakıflara ait iktisadi işletmelerin sermayelerinin tamamı vakfa ait olduğundan bağlı ortaklık olarak değerlendirilmiş ve bağlı ortaklık hesabı, iktisadi işletme hesabı ile birlikte kullanılmıştır.

- Vakıflar kâr gayesi gütmeyen mal topluluğu niteliğinde medeni hukuk tüzel kişileridir. Dolayısıyla sermaye şirketleri ve diğer iktisadi işletmelerin kuruluş gayelerinin esaslarını oluşturan sermaye, kâr ve zarar kavramları, vakıf tüzel kişiliği ile bağdaşmamaktadır. Bu kavramların vakıf hukukundaki karşılıkları Vakıf Mal Varlığı ve Gelir veya Gider Fazlalıklarıdır. Aynı şekilde Sermaye Yedekleri ve Kâr Yedekleri kavramlarının da bu açıklamalar doğrultusunda değerlendirilmesi gerekmektedir. 
Uluslararası Yönetim İktisat ve İsletme Dergisi, ICAFR 16 Özel Sayısı Int. Journal of Management Economics and Business, ICAFR 16 Special Issue

- Kar yedekleri kısmında yer alan 543 Matematik Karşılıkları Hesabı ve 544 Ödenmiş Primler Karşılığı Hesabı sandık ve munzam vakıflar için oluşturulmuştur.

- Vakfa yurtiçinden ve yurtdışından yapılan ayni ve nakdi, şartlı veya şartsız bağış ve yardımlar 603 Bağış ve Yardımlar hesabının alt hesaplarında takip edilmelidir. Vakıfların, bağışlara ve yardımlara dayalı değil, sağlam gelir kaynaklarına göre faaliyet yapmaları esastır. Ayni bağışlar rayiç bedelle muhasebeleştirilirler.

- Dönem içinde üyelerden alınan prim ve aidatlar 604 Prim ve Aidatlar hesabında izlenir.

- Giderler, dönem sonunda yansitma hesabına devredilirken faaliyet giderleri ve amaca yönelik giderler olarak ayrıştırılmalıdır. 633 Amaca Yönelik giderler hesabı; vakıf senedinde yer alan vakıf amaçlarına yönelik olarak yapılan endirekt malzeme, endirekt işçilik, personel giderleri, dışarıdan sağlanan fayda ve hizmetler, çeşitli giderler, vergi resim ve harçlar, amortismanlar ve tükenme paylarından oluşur.

- 648 İktisadi İşletme Gelirleri hesabında vakfa ait iktisadi işletmelerden elde ettiği gelirler (vergi sonrası kar) takip edilir.

\subsubsection{Vakıflarda Muhasebe Kayıtları}

\section{Vakıflarda Kuruluş Muhasebe Kayıtları}

Vakıflar, tanımlarına uygun olarak belli bir amacın gerçekleştirilmesi için bir mal veya hakkın gelirleriyle birlikte tahsis edilmesi suretiyle kurulurlar. Vakfin kuruluşu esnasında tahsis edilen mallar onun kuruluş mal varlığıdır. Muhasebe kayıtları, bu mal varlığının açılış bilançosuna uygun bir şekilde kayıtlara yansıtılması ile başlar. Vakfın kuruluşu için tahsis edilen mal varlığı, tahsis etme tarihindeki değeri ile kayıtlara intikal ettirilir. Bu konuda 213 sayılı Vergi Usul Kanunu'ndaki 269-297 sayılı değerleme hükümleri uygulanır (Kayıhan, 2012:5).

Örnek: Yurt içinde tedavi ettirilemeyen hastaların yurt dışında tedavi ettirilmesi için özel ihtisas hastaneleri kurulması amacıyla bir vakıf kurulmasına karar verilmiştir. $\mathrm{Bu}$ amaçla emlak vergisi değeri $150.000 \mathrm{TL}$ olan bir ev, 260.000 TL olan bir arsa, 40.000 TL para, 35.000 TL hisse senedi ve 10.000 TL hazine bonosu tahsis edilmek suretiyle 05.07.2010 tarihinde (A) Sağlık Hizmetleri Vakfı adı altında bir vakıf kurulmuştur.

(A) Sağlık Hizmetleri Vakfı'nın kuruluş muhasebe kayıtları aşağıdaki gibidir:

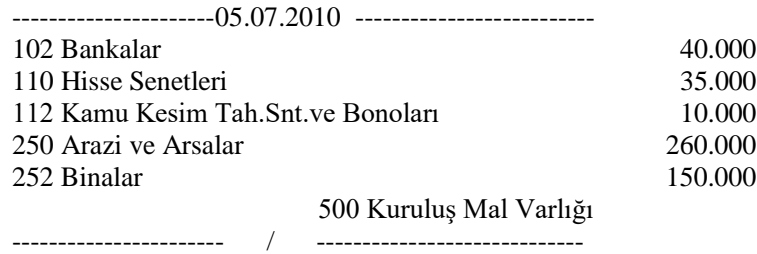

Vakfin Şube Açılışı Muhasebe Kayıtları 
Uluslararası Yönetim İktisat ve İsletme Dergisi, ICAFR 16 Özel Sayısı Int. Journal of Management Economics and Business, ICAFR 16 Special Issue

Örnek: Kültür ve tabiat varlıklarının korunması ve bilimsel araştırmalar yapılması amacı ile İstanbul'da kurulan B Bilimsel Araştırmalar ve Kültür Vakfı uzun zamandır sürdürdüğü faaliyetlerini daha etkin hale getirmek için şube açmaya karar vermiştir. Bu çerçevede 10.06.2012 tarihinde İzmir ilinde kurulması kararlaştırılan şube için; 20.000 TL para şubenin açılan banka hesabına yatırılmış ve ayrıca değeri 5.500 TL olan demirbaş tahsis edilmiştir.

Şube açılış muhasebe kayıtları aşağıdaki gibi olacaktır:

$\begin{array}{lrrr}102 \text { Bankalar } & & & \\ 255 \text { Demirbaşlar } & & 20.000 & \\ & 500 \text { Kuruluş Mal Varlığı } & & \\ & & & 25.500\end{array}$

Vakıf Genel Merkez muhasebe kayıtları aşağıdaki gibi olacaktır:

\begin{tabular}{|c|c|c|}
\hline \multirow{2}{*}{ 245 Bağlı Ortaklıklar } & \multicolumn{2}{|c|}{25.500} \\
\hline & $\begin{array}{l}102 \text { Bankalar } \\
255 \text { Demirbaslar }\end{array}$ & $\begin{array}{r}20.000 \\
5.500\end{array}$ \\
\hline
\end{tabular}

\section{Vakfa Ait İktisadi İşletmenin Açıışında Vakıf Genel Merkezinin Muhasebe Kayıtları}

Vakıflar amaçlarını daha etkin yerine getirebilmek amacı ile iktisadi işletme kurabilecekleri gibi herhangi bir ticari işletmeye veya sermaye şirketine ortak olabilirler. Söz konusu ortaklık sermaye payına göre bağlı ortaklık veya iştirak olabilir. Açılan iktisadi işletmeler tamamen vakfa bağlı ve vakfa aittirler. İktisadi İşletmeler ve şubeler için ayrı karar defteri tasdik ettirilir ve ayrı sorumlular atanır. İktisadi işletme ve şubenin varlığı halinde yıl sonunda bireysel finansal tablolar konsolide edilir.

Örnek: (C) Sosyal Yardımlaşma ve Dayanışma Vakfı mütevelli heyeti, sürdürdüğü faaliyetleri daha etkin hale getirmek ve ilçedeki genç kızların iş hayatına aktif katılımını sağlamak amacıyla dokumacılık faaliyetlerinde bulunmak üzere bir iktisadi işletme kurmaya karar vermiştir. Bu maksatla gerekli kanuni işlemler tamamlandıktan sonra, mevcut binalarının 80.000 TL'lik bir kısmını X Dokumacılık İşletmesi'ne tahsis etmiştir. Ayrıca kullanılacak 45.000 TL'lik demirbaşın bedelini banka hesabından karşılayarak X Dokumacılık İşletmesi'ne tahsis etmiş ve 5.000 TL'yi de Dokumacılık İşletmesi adına bankada açtığı hesaba yatırmıştır. Vakıf Genel Merkez muhasebe kayıtları aşağıdaki gibi olacaktır:

\begin{tabular}{|c|c|c|c|}
\hline \multicolumn{2}{|c|}{245 Bağ $1_{1}$ Ortaklıklar (İkt. İsletmeler) } & \multirow[t]{2}{*}{130.000} & \multirow[b]{2}{*}{130.000} \\
\hline & $\begin{array}{l}246 \text { Bağ.Ort.Serm.Taah. } \\
\text { (İkt.İşletmelere) }\end{array}$ & & \\
\hline $\begin{array}{l}246 \text { Bağ.Ort.Serm.Taah. } \\
\text { (İkt.İşletmelere) }\end{array}$ & & 100.000 & \\
\hline & $\begin{array}{l}102 \text { Bankalar } \\
252 \text { Binalar }\end{array}$ & & $\begin{array}{l}50.000 \\
80.000\end{array}$ \\
\hline
\end{tabular}


Uluslararası Yönetim Íktisat ve İsletme Dergisi, ICAFR 16 Özel Sayısı Int. Journal of Management Economics and Business, ICAFR 16 Special Issue

Vakfin Faaliyeti Sürecinde Muhasebe Kayıtları

Vakfa yapılan şartlı ya da şartsız bağışların banka hesabına yatırılması;

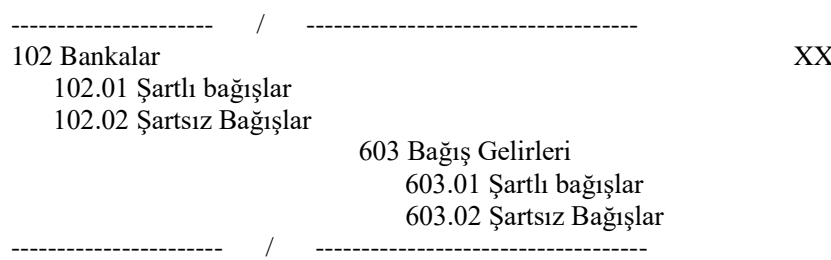

XX

Vakfın elde ettiği gelirlerden, amacına göre yapmış olduğu yardım ödemelerini banka aracılığıyla yapması;

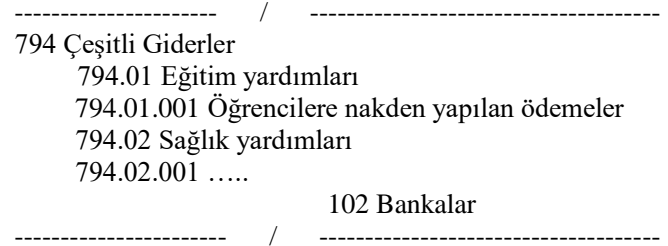

794.01 Eğitim yardımları

O9.01.001 Ŏrencilere nakden yapılan ödemele

794.02 Sağlık yardımlar

$\mathrm{XX}$

Vakıfların olağan ödemelerinin (elektrik, su, telefon v.b) banka aracılığıyla yapılması;

793 Dışarıdan Sağlanan Fayda
$\begin{aligned} & \text { Ve Hizmetler } \\ & \text { 793.01 Elektrik }\end{aligned}$
$\begin{aligned} & 102 \text { Bankalar } \\ & 102.02 \text { Şartsız Bağışlar }\end{aligned}$

$\mathrm{XX}$

XX

Vakıfların normal faaliyetlerinin devamı için kira, sigorta, kırtasiye, 1sınma vb. giderlerinin banka aracılığıyla yapılması;

$\begin{array}{ccc}\text { 794 Çeşitli Giderler } & \text { XX } & \\ & 102 \text { Bankalar } & \\ & 102.02 \text { Şartsı Bağışlar } & \\ & & \end{array}$

Vakıfların iktisadi işletmelerinden elde ettikleri gelirlerin banka hesabına yatırılması;

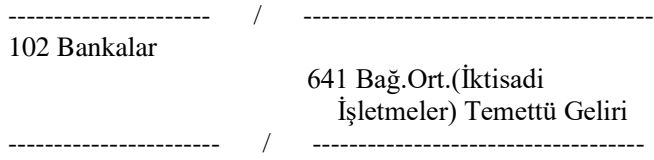

XX

$\mathrm{XX}$

Vakıfların mutad ödemelerinin (eletrik,su,telefon v.b) geç yapılmasından doğan fark ve cezaların kurucular tarafindan ödenmesi;

131 Ortaklardan (Kuruculardan) Alacaklar

$\mathrm{XX}$

100 Kasa

XX 
Uluslararası Yönetim İktisat ve Işsletme Dergisi, ICAFR 16 Özel Sayısı Int. Journal of Management Economics and Business, ICAFR 16 Special Issue

Vakıfların yapmış olduğu faaliyetlerden (kermes vb.) elde ettikleri gelirlerin tahsili;

$\begin{array}{lc}\text { 100 Kasa } & \text { / } \\ & \\ & \end{array}$

$\mathrm{XX}$

$\mathrm{XX}$

\section{Vakıfların Türk Vergi Mevzuatı Karşısındaki Durumu}

\subsection{Vakıflarda Vergi Muafiyeti}

Vergi mevzuatı genel olarak STK'ların lehine ve mali sürdürülebilirliği destekler nitelikte olmamakla birlikte bir takım istisnalar ve teşvikler sağlamaktadır. Sivil toplum kuruluşları için vergi istisna veya muafiyetlerinden yararlanmanın en önemli aracı kamu yararına çalışan dernek veya vergi muafiyetine sahip vakıf statüsüne sahip olunmasidir ${ }^{6}$.

Gelirlerinin en az üçte ikisini nevi itibarıly genel ve özel bütçeli idarelerin bütçeleri içinde yer alan bir hizmetin veya hizmetlerin yerine getirilmesini amaç edinmek üzere kurulan vakıflar ile münhasıran devlet üniversitelerinin faaliyetlerinin devam ettirilmesi ve desteklenmesi amacıyla kurulan vakıflara Maliye Bakanlığının önerisi üzerine Bakanlar Kurulunca vergi muafiyeti tanınabilir. Bakanlar Kurulunca vergi muafiyeti tanınacak vakfın; sağlık, sosyal yardım, eğitim, bilimsel araştırma ve geliştirme, kültür ve çevre koruma ile ağaçlandırma gibi konuların bir veya birden fazlasında faaliyette bulunmayı amaç edinmiş olması gerekir. Ayrıca vakfin bu faaliyetlerinin kamuya açık ve devletin kamu hizmeti yükünü azaltıcı etki yapacak düzeyde olması, kuruldukları tarihten itibaren en az bir yıl süre ile faaliyette bulunması, bilanço esasına göre defter tutmaları, vergi muafiyeti talebinde bulundukları tarihte 2012 yılı için en az 733.000 TL gelir getirici mal varlı̆̆ına ve en az 69.000 TL yıllık gelire sahip olmaları gibi şartları bulundurmaları gerekmektedir?

Bireysel ve kurumsal bağışı teşvik etmek amacıyla verilen vergi indirimleri, kredileri ya da diğer vergi olanakları Türkiye'de çok sınırlıdır. Bireyler beyan edilmiş gelirlerinin \%5'ine kadar olan kısmını kamu yararı statüsüne veya vergi muafiyetine sahip olan STK'lara bağışlamaları kaydıyla vergiden düşebilmektedir. Kalkınma önceliği taşıyan belli coğrafi bölgelerde bu oran \%10'a kadar yükseltilmiștir. Ancak yukarıda da belirtildiği gibi kamu yararı statüsü ya da vergi muafiyeti olan STK'lar derneklerin sadece \%1'ini, vakıfların ise \%7'sini oluşturmaktadır ve bu statüyü almak için gereken şartlar ve süreç oldukça zordur ${ }^{8}$.

\subsection{Vakıfların 5520 Sayılı Kurumlar Vergisi Kanunu Açısından Değerlendirilmesi}

5520 sayılı Kurumlar Vergisi Kanununun 1 inci maddesine göre vakıfların tüzel kişiliği itibariyle kurumlar vergisi mükellefiyeti bulunmamaktadır. Vakfa bağlı iktisadi işletmeler ise, diğer kurumlar vergisi mükellefleri gibi kurum kazancı üzerinden kurumlar

\footnotetext{
${ }^{6}$ http://www.tusev.org.tr/usrfiles/files/Vergi_Bilgi_Notu.pdf

7 www.gib.gov.tr Vakıfların Vergilendirilmesi Rehberi, Ekim 2012, 12-13-17.

${ }^{8}$ http://www.tusev.org.tr/usrfiles/files/Vergi_Bilgi_Notu.pdf
} 


\section{Uluslararası Yönetim İktisat ve İşletme Dergisi, ICAFR 16 Özel Sayısı Int. Journal of Management Economics and Business, ICAFR 16 Special Issue}

vergisi hesaplayacaktır. Dernek ve vakıfların iktisadi işletmelerinin vergilendirilmesinin nedeni ekonomideki rekabet eşitliğini sağlamak şeklinde açıklanabilir.

Ancak, Kurumlar Vergisi Kanununun 7. maddesinin 7 numaralı bendinde ilim, fen ve güzel sanatlar ile tarım ve hayvancılığı öğretmek, yaymak, ıslah ve teşvik etmek, genel insan ve hayvan sağlığını korumak ve tedavi etmek, sosyal amaçlı faaliyetlerde bulunmak üzere işletilen müesseseler ile Hükümetin veya yetkili idare mercilerinin izni ile açılan mahalli, milli veya milletlerarası mahiyetteki sergiler, fuarlar ve panayırlardan vakıflara ait olup sayılan amaçlarla işletildikleri ilgili bakanlıkların görüşü alınmak suretiyle Maliye Bakanlığı'nca kabul edilenler vergiden muaf tutulmuşlardır. Dolayısıyla, vergiden muaf olsun veya olmasın bir vakfa ait olup, yukarıda sayılan konularda faaliyet gösteren ve belirtilen şekilde ve bu amaçla faaliyet gösterdiği ilgili bakanlığın görüşü de alınarak Maliye Bakanlığınca kabul edilen iktisadi işletmeler kurumlar vergisinden muaf tutulabilmektedir (Arslan, 1996:87-88). KVK'nın bu hükmü ve 2547 sayılı Yükseköğretim Kanunu'nun ilgili hükmü beraber düşünüldüğünde vakıf üniversiteleri ile hastanelerin kamu kurum ve kuruluşları gibi kurumlar vergisinden muaf oldukları sonucuna ulaşmaktayız (Alantar, 2011:27).

\subsection{Vakıfların 193 Sayılı Gelir Vergisi Kanunu Açısından Değerlendirilmesi}

Vakıflar, tüzel kişiliğe sahip olduklarından, yani gerçek kişi olmadıklarından, Gelir Vergisi mükellefi değildirler. Genel ilke bu olmakla birlikte, Gelir Vergisi Kanununun 94'üncü maddesinin bazı hükümleri vakıfları da ilgilendirmektedir (Konca, 2006:80)

Vakıflar, Gelir Vergisi Kanununun 94'üncü maddesinde nakden veya hesaben ödeme yaptıkları sırada, istihkak sahiplerinin gelir vergilerine mahsuben tevkifat yapmaya mecbur tutulanlar arasında sayılmıştır ${ }^{9}$. Anılan maddeye göre; vakıflar (mazbut vakıflar hariç) ve derneklere ait gayrimenkullerin kiralanması karşılığında bunlara yapılan kira ödemelerinden \% 25 vergi tevkifatı yapılır (Yalçın ve Öz, 2011:173). Vakıfta istihdam olunan personele ödenen asgari geçim indirimi tutarı, ödemeye müteakiben verilecek muhtasar beyannamede hesaplanan gelir vergisinden mahsup edilecektir.

\subsection{Vakıfların 3065 Sayılı Katma Değer Vergisi Kanunu Açısından Değerlendirilmesi}

KDV Kanunu'nun 1. maddesinde, KDV'ye tabi işlemler belirtilmiştir. KDV'nin mükellefi, vergiye konu (ticari, sinai, zirai faaliyet ve serbest meslek faaliyeti çerçevesinde yapılan teslim ve hizmetler, her türlü mal ve hizmet ithalatı, diğer faaliyetlerden doğan teslim ve hizmetler) işlemleri yapanlardır.

Vakıflar KDV Kanunu'nun 1. maddesinde belirtilen işlemleri yapmaları halinde, KDV mükellefi olacaklardır.

Ancak, vakıflar, hukuki yapıları gereği, ticari, sınai ve zirai faaliyetleri, iktisadi işletmeleri aracılığıyla yapabileceklerinden, doğrudan mükellefiyetleri söz konusu değildir (Konca, 2006:83).

\footnotetext{
9 www.gib.gov.tr Vakıfların Vergilendirilmesi Rehberi, Ekim 2012, 4.
} 
Uluslararası Yönetim İktisat ve Işletme Dergisi, ICAFR 16 Özel Sayısı Int. Journal of Management Economics and Business, ICAFR 16 Special Issue

3065 sayılı Katma Değer Vergisi Kanunu’na göre vakıfların iktisadi işletmelerinin yapmış oldukları teslim ve hizmetler ve bu iktisadi işletmelere yapılan her türlü teslim ve hizmetler katma değer vergisine tabidir (Erdem, 2013:3).

Bakanlar Kurulunca vergi muafiyeti tanınmış vakıflara KDV Kanunu'nun 17.maddesi ile KDV istisnası hakkı tanınmıştır. Bunlar;

\section{Kültür ve eğitim amacı taşıyan istisnalar;}

- $\quad$ İlim, fen ve güzel sanatları, tarımı yaymak, ıslah ve teşvik etmek amacıyla yaptıkları teslim ve hizmetleri,

- Tiyatro, konser salonu, kütüphane, sergi, okuma ve konferans salonları ile spor tesisleri işletmek veya yönetmek suretiyle ifa ettikleri kültür ve eğitim faaliyetlerine ilişkin teslim ve hizmetleri.

\section{Sosyal amaç taşıyan istisnalar;}

- Hastane, nekahathane, klinik, dispanser, pirevantoryum, sanatoryum, kan bankası ve organ nakline mahsus bankalar, anıtlar, botanik ve zooloji bahçeleri, parklar ile veteriner, bakteriyoloji, seroloji ve distofajin laboratuvarları gibi kuruluşlar, öğrenci veya yetiştirme yurtları, yaşlı ve sakat bakım ve huzurevleri, parasız fukara aşevleri, düşkünevleri ve yetimhaneleri işletmek veya yönetmek suretiyle ifa ettikleri kuruluş amaçlarına uygun teslim ve hizmetleri.

\subsection{Vakıfların 7338 Sayılı Veraset ve İntikal Vergisi Kanunu Açısından} Değerlendirilmesi

Veraset ve İntikal Vergisi Kanunu'nun 1. maddesine göre, bir şahsa hakiki veya hükmi ait malların veraset yoluyla veya herhangi bir suretle olursa olsun ivazsız (karş1lıksı) bir tarzda başka bir şahsa intikali, veraset ve intikal vergisine tabidir. "İvazsız intikal"den kasıt, karşılıksız kazanımlardır. Vakıflar ve dernekler, esas itibariyle Veraset ve İntikal Vergisi mükellefidirler.

\section{Vakıf ve derneklere ilişkin muafiyetler:}

Veraset ve İntikal Vergisi Kanunu'nun “muafiyetler”i düzenleyen 3. maddesinin (a) bendine göre kamu menfaatine yararlı dernekler, (b) bendine göreyse kamu yararı için ilim, araştırma, kültür, sanat, sağlık, eğitim, din, hayır, imar, spor gibi amaçlarla kurulan vakıflar, veraset ve intikal vergisinden muaf olacaklardır.

\section{Vakıflara ilișkin istisnalar:}

Veraset ve İntikal Vergisi Kanunu'nun “istisnalar”a ilişkin 4. maddesinin, (k) fikrası aynen şöyledir:"Bakanlar Kurulu'nca vergi muafiyeti tanınan vakıflara kuruluşlarında ve kurulduktan sonra tahsis olunan mallar için Veraset ve İntikal Vergisi ödenmeyecektir.

\subsection{Vakıfların 1319 Sayılı Emlak Vergisi Kanunu Açısından Değerlendirilmesi}

Vakıflar vergiden muaf olsa dahi sahibi oldukları bina, arsa ve araziler için belirtilen süreler içinde taşınmazın bulunduğu yerin belediye vergi dairesine emlak vergisi beyannamesini vereceklerdir. 
Uluslararası Yönetim İktisat ve İşletme Dergisi, ICAFR 16 Özel Sayısı Int. Journal of Management Economics and Business, ICAFR 16 Special Issue

Emlak Vergisi Kanununun 4. maddesinin (m) bendine göre; Bakanlar Kurulunca vergi muafiyeti tanınan vakıflara ait binaların, vakıf resmi senedindeki amaca tahsis edilmek koşuluyla emlak vergisinden muaf tutulacağı hükme bağlanmıştır. Dolayısıyla, Emlak Vergisi Kanuna göre Bakanlar Kurulunca vergi muafiyeti tanınan vakıflar dışında kalan diğer vakıflar Emlak Vergisine tabidirler.

\subsection{Vakıfların 197 Motorlu Taşıt Vergisi Kanunu Açısından Değerlendirilmesi}

Motorlu Taşıtlar Vergisi'nin mükellefi, trafik sicili ile Ulaştırma Bakanlığınca tutulan sivil hava vasıtaları sicilinde adlarına motorlu taşıt kayıt ve tescil edilmiş olan gerçek ve tüzel kişilerdir.

Motorlu Taşıtlar Vergisi Kanunu'nun 4. maddesinde istisnalar yer almaktadır. Ancak bu istisnalar arasında vakıflara ilişkin bir düzenleme bulunmamaktadır. Vakıflar, MTV ve Taşıt Alım Vergisi mükellefidirler.

\subsection{Vakıfların 488 Damga Vergisi Kanunu Açısından Değerlendirilmesi}

488 sayılı Damga Vergisi Kanununun 9 uncu maddesi uyarınca, damga vergisinden istisna edilen kağıtların belirtildiği Kanuna ekli (2) sayılı tablonun "V. Kurumlarla ilgili kağıtlar" başlıklı bölümünün 19 numaralı fikrasında, Bakanlar Kurulunca vergi muafiyeti tanınan vakıfların kuruluş işlemlerinde düzenlenen her türlü kağıtlarla, Türk Silahlı Kuvvetlerini (Jandarma Genel Komutanlığı dahil) güçlendirmek amacıyla kurulmuş vakıfların her türlü işlemlerinde düzenlenen kağıtların damga vergisinden istisna olduğu hükme bağlanmıştır ${ }^{10}$

Vakıflar, 3294 sayılı Kanunun 9/(c) maddesine göre damga vergisinden muaf olmaları nedeniyle sözleşme, fatura, muhtasar beyanname ile sigorta prim bildirgeleri vb. düzenlemeler için damga vergisi hesaplaması ve ödemesi yapmayacaklardır.

\subsection{Vakıfların 492 Harçlar Kanunu Açısından Değerlendirilmesi}

Harçlar Kanunu'nun 1. maddesi, harç alınacak işlemleri, 9 (dokuz) grup halinde toplamıştır. Bunlardan vakıfları yakından ilgilendirenler, yargı harçları, noter harçları, vergi yargısı harçları, tapu ve kadastro harçlarıdır.

- Yargı harçlarında, vakıflar için bir istisna ve muaflık söz konusu değildir.

- Noter harçlarında, Bakanlar Kurulunca vergi muafiyeti tanınan vakıfların kuruluş muameleleriyle bu vakıflara yapılacak bağışlamalar harca tabi tutulmaz.

- Vergi yargısı harçlarında, herhangi bir istisna ya da muaflık söz konusu değildir.

- Tapu ve Kadastro harçlarında ise, anılan yasanın 59. maddesinin 1. fikrasının (b) bendinde belirtilen işlemlerde, kamuya yararlı derneklerle Bakanlar Kurulu'nca vergi muafiyeti tanınan vakıflar harçtan istisna edilmiştir.

10 www.gib.gov.tr Vakıfların Vergilendirilmesi Rehberi, Ekim 2012, 14. 


\section{Uluslararası Yönetim İktisat ve İsletme Dergisi, ICAFR 16 Özel Sayısı Int. Journal of Management Economics and Business, ICAFR 16 Special Issue}

Vakıf iktisadi işletmeleri Emlak Vergisi Kanunu, Motorlu Taşıtlar Vergisi Kanunu, Damga Vergisi Kanunu, Harçlar Kanunu'na tabi olup mükellefiyet açısından herhangi bir muafiyet ve istisna bulunmamaktadır (Erdem, 2013:3).

\section{Sonuç}

Vakıflar ait oldukları toplumun eğitimine, kültürüne, sosyal ve siyasal yaşamlarına büyük katkılar sağlamalarının yanında; günümüzde kamu ve özel sektörün dışında ekonomiye yön veren üçüncü sektör olarak kabul edilen sivil toplum kuruluşları içerisinde önemli bir yere sahiptir. Bilindiği gibi vakıfların özellikleri arasında, kâr elde etmek amacıyla kurulmamaları, öz kaynaklarının gerçek veya tüzel kişilere ait paylara ayrılmaması, gelir fazlalıklarının bölüştürülmemesi, devredilmemesi ve satılamaması gelir.

Muhasebe uygulamaları; ticari amaçlı işletmeler yanında, kazanç paylaşma amacı dışında kurulan ve belirli bir kaynak kullanan, kaynak kullanımını bütçeleyip denetleyen toplumsal amaçlı kuruluşlar için de zorunludur. Vakıfların, kar amacı gütmeyen kuruluşlardan olması bunlarda uygulanan muhasebe uygulamalarının diğer işletmelerden farklı olması sonucunu doğurmuştur. Vakıflar Genel Müdürlüğünce hazırlanan Vakıflar Tek Düzen Hesap Planı ile; vakıflardaki mali işlemlerin belli kavram ve ilkeler çerçevesinde muhasebeleştirilmesi, ilgililere tutarlı ve karşılaştırılabilir mali tablolar sunulmasının sağlanması ve böylelikle vakıf denetimlerinin de kolaylaştırılması amaçlanmıştır. Ancak ülkemizde vakıfların kullandığı muhasebe ve raporlama standartları genel olarak ticari kuruluşların ihtiyaçlarına ve kullanımlarına dönüktür ve bugüne kadar vakıflara özgü muhasebe standartları henüz belirlenmemiştir. Vakıflar için anlaşılabilir, şeffaf, devlet maliyesinin, vakıf kurucu ve yöneticilerinin, üyelerinin, vakıflara bağış ve yardım yapanların, onlara gerektiğinde kredi ve fon verecek kuruluşların ve genel olarak toplumun mali tablolardan beklediği ihtiyaçlara cevap verecek muhasebe standartları oluşturulmalıdır.

Vakıfların tüzel kişilikleri itibariyle hayır amacına yönelik kuruluşlar olması nedeniyle bu kuruluşların vergilendirilmesinde de diğer iktisadi işletmelere göre bir takım muafiyet ve istisnalara sahip oldukları söylenebilir. Vakıfların vergilendirilmesinde, vakıfların tüzel kişiliklerinin dışında iktisadi işletmelerinin bulunup bulunmaması veya vakfın vergiden muaf bir vakıf olması gibi durumlar vergilendirme esnasında özellik arz etmektedir. Bununla birlikte vakıf tüzel kişiliklerine tanınan ayrıcalıklar nedeniyle bu kuruluşların ticari ilişkilerde araç olarak kullanıldığı; normal olarak ticari işletmeler aracılığıyla yapılması gereken iktisadi faaliyetlerin vakıf bünyesinde gerçekleştiği görülmektedir. $\mathrm{Bu}$ nedenle, bu kuruluşlara yönelik vergi tedbirlerinin bir yandan gerçekten gerekli ve etkili olması arzu edilirken, diğer yandan da haksız rekabet yaratmamasına da özen gösterilmelidir. Aynı zamanda tanınan ayrıcalıklar neticesinde vakıfların amaçları doğrultusunda çalışıp çalışmadıklarını denetlemek ayrı bir önem taşımaktadır.

\section{Kaynakça}

Alantar, D. (2011). Vakıf üniversitelerinin kurumlar vergisi ve kdv açısından durumu. Yaklaşım, Y11:19, Sayı 225, 26-30.

Arslan, E. (1996). Vakıfların Vergi Kanunları Karşısındaki Durumu Ve Vergi 
Uluslararası Yönetim İktisat ve İsletme Dergisi, ICAFR 16 Özel Sayısı Int. Journal of Management Economics and Business, ICAFR 16 Special Issue

Muafiyeti, Vakıfların Ekonomiye Katkısı Ve Üçüncü Sektör Ve Konya Alâeddin Camii Restorasyonu Seminerleri. XIII Vakıf Haftası Kitabı, Vakıflar Genel Müdürlüğü Yayınları, Ankara, 87-88.

Durmuş, A.H. (2011). Vakıflar muhasebesi, İstanbul Ticaret Üniversitesi Yayınları, İst

Durmuş, A.H. (2012). Vakıflarda bina edinmelerinin muhasebeleștirilmesi.İstanbul Ticaret Üniversitesi Sosyal Bilimler Dergisi, Y1l:11, Say1:21, 2012, 469-492.

Erdem, D. (2013). Vakıf iktisadi işletmelerinde muhasebe uygulamaları.

http://www.muhasebeokulu.com/makaleler/vakif-iktisadi-isletmelerindemuhasebe-uygulamalari/

Erşahin, S. (2003). Vakıf düşüncesini doğuran temel dinamikler üzerine. Vakıf Medeniyeti Sempozyum Kitabı,Vakıflar Genel Müdürlüğü Yayını, Ankara.

Kayıhan, Y. (2012). Vakıflarda muhasebe ve vergi uygulamaları. Serbest Muhasebeci ve Mali Müşavirler Odası Semineri, Bursa.

http://www.bursa-smmmo.org.tr/bsmmmo/index.php?site=tesmer\&blm=seminernot $(23$ Mart 2012)

Konca, M. (2006). Sivil toplum kuruluşları için muhasebe, finansman ve vergi uygulamalarına giriş, İstanbul, 1.Baskı, İstanbul Bilgi Üniversitesi Yayınları.

Kurt, İ. (2013). Şer’i açıdan vakıf ve vakıfların muhasebe usulü. İslâmî İlimler Araştırma Vakfı Yayını, İstanbul, 1-52. isav@isavvakf.org

Saydam, O. Ekici, M. (1998). Türk medeni kanununa göre vakıf. 2.Baskı, İstanbul, Sev Yayınları.

Şahin, H. (2013). Bireysel ve kurumsal bağışçılar için yasal ve vergisel düzenlemeler rehberi. Türkiye Üçüncü Sektör Vakfı Yayını.

http://www.tusev.org.tr/usrfiles/files/vergiselkonularrehberi_web_29_08_13.pdf

Şanlı, Ç., (1980), “Türkiye'de Kar Amaçsız İşletmelerin Muhasebe Eğitimi Sorunları”, II.Türkiye Muhasebe Eğitimi Sempozyumu, Çeşme.

Özdemir, S. Basel, H. ve Şenocak, H. (2009). Sivil toplum kuruluşları (stk)'nın artan önemi ve üsküdar'da faaliyet gösteren bazı stk'lar üzerine bir araştırma, Sosyal Siyaset Konferansları, 56.Kitap, İstanbul Üniversitesi Yayınları, 151-234.

Öğredik, G. (2005). Vakıflar ve vakıf iktisadi işletmelerinin vergi mevzuatı açısından incelenmesi. E-Yaklaşım, Sayı:22,1-26.

(http://www.mazarsdenge.com.tr/printerFriendly.php?contentId=138)

Yalçın, A. Öz, Y. (2011). Sivil toplum örgütleri için hukuk rehberi. 2.Baskı, Odak Ofset Matbaacilık, Ankara, 1-1050.

08.12.2001 tarihli ve 24607 sayılı Resmi Gazete

Vakıflar Genel Müdürlüğü. http://www.vgm.gov.tr/icerik.aspx?Id=20 
Uluslararası Yönetim İktisat ve İşletme Dergisi, ICAFR 16 Özel Saylsı Int. Journal of Management Economics and Business, ICAFR 16 Special Issue

Sosyal Yardımlaşma Ve Dayanışma Vakfı Kayıt Nizamı 10/12/2010

http://www.sosyalyardimlar.gov.tr/upload/sosyalyardimlar.gov.tr/mce/2008-

2010/birimler/kaynak_yonetimi/syd_vakiflari_kayit_nizami.pdf

Vakıfların Vergilendirilmesi Rehberi, Gelir İdaresi Başkanlığı, Yayın No:152, Ekim 2012. www.gib.gov.tr

Türkiye Üçüncü Sektör Vakfi

http://www.tusev.org.tr/usrfiles/files/Vergi_Bilgi_Notu.pdf

5737 Sayılı Vakıflar Kanunu, Vakıflar Yönetmeliği, Vakıflar Hakkında Tüzük, 1 Seri No.lu Vakıflara Vergi Muafiyeti Tanınması Hakkında Genel Tebliğ, 193 Sayılı Gelir Vergisi Kanunu, 197 Sayılı Motorlu Taşıtlar Vergisi Kanunu, 213 Sayılı Vergi Usul Kanunu, 488 Sayılı Damga Vergisi Kanunu, 492 Sayılı Harçlar Kanunu, 1319 Sayılı Emlak Vergisi Kanunu, 3065 Sayılı Katma Değer Vergisi Kanunu, 4721 Sayılı Türk Medeni Kanunu, 5520 Sayılı Kurumlar Vergisi Kanunu, 6102 Sayılı Türk Ticaret Kanunu, 7338 Sayılı Veraset ve İntikal Vergisi Kanunu 